\title{
Reply \\ MI Receptor Agonism, a Possible Treatment for Cognitive Deficits in Schizophrenia
}

\author{
Katerina Zavitsanou* \\ Neuroscience Institute of Schizophrenia and Allied Disorders (NISAD), Department of Biomedical Sciences, University of Wollongong, Northfields \\ Avenue, NSW 2522, Australia
}

Neuropsychopharmacology (2004) 29, I585-1586. doi:I0.1038/s..npp. 1300509

Sir

There is now a great deal of evidence implicating the involvement of acetylcholine in cognitive processes relevant to schizophrenia (Friedman et al, 1999). This in turn provides potential for remediation strategies by manipulation of acetylcholine and/or its receptors. In response to our recently published paper in this journal (Zavitsanou et al, 2004), Brian Dean provided evidence that muscarinic M1 receptor agonism might be a possible treatment for cognitive deficits in schizophrenia.

Cognitive processes relevant to schizophrenia are mediated by the anterior cingulate cortex (ACC, Brodman's area 24), which plays an important role in attention control (Bush et al, 2000) and the prefrontal cortex, which is involved in working memory and executive function (Goldman-Rakic, 1987). In our recently published paper (Zavitsanou et al, 2004), we reported a decrease in $\left[{ }^{3} \mathrm{H}\right]$ pirenzepine binding to M1 and M4 muscarinic receptors in ACC samples taken post-mortem from patients with schizophrenia. In agreement with our results are postmortem studies showing significant reductions of $\left[{ }^{3} \mathrm{H}\right]$ pirenzepine binding within the prefrontal cortex (Brodman's area $8,9,10$, and 46$)$ of patients suffering with schizophrenia (Crook et al, 2001; Dean et al 2002). Taken together, these studies indicate similar deficits in muscarinic M1/M4 receptors in cortical areas involved in different aspects of cognition.

Unfortunately, without specific ligands it is difficult to assign a specific muscarinic receptor subtype to deficits observed in both post-mortem and neuroimaging studies (eg Raedler et al, 2003). Whereas in BA9, a decrease in

\footnotetext{
*Correspondence: Dr K Zavitsanou, Neuroscience Institute of Schizophrenia and Allied Disorders (NISAD), Department of Biomedical Sciences, University of Wollongong, Northfields Avenue, NSW 2522, Australia, Tel: +61 2 42213199, Fax: +61 2 42214096,

E-mail: katerina_zavitsanou@uow.edu.au

Received 27 April 2004; accepted 03 May 2004

Online publication: 15 May 2004 at http://www.acnp.org/citations/ Npp05 I 50404200/default.pdf; http://www.acnp.org/citations/

Npp05 I50404089/default.pdf
}

$\left[{ }^{3} \mathrm{H}\right]$ pirenzepine binding was associated with a decrease in M1 but not M4 receptor protein and mRNA (Dean et al, 2002), no data are available to support a similar association in the ACC. Studies with muscarinic receptor knockout mice have begun to offer some enhanced understanding of the role of muscarinic receptor subtypes in cognition and psychosis. In this context, it is of interest that M1 receptor knockout mice show abnormalities in memory-relative cognitive behaviors (Anagnostaras et al, 2003), whereas mice lacking the M4 receptor show a deficit in prepulse inhibition of the startle reflex, a measure of attention (Felder et al, 2001).

Recent studies using acetylcholinesterase inhibitors support the notion that activation of cholinergic receptors would be an effective approach to reversing the cognitive deficits in schizophrenia (Buchanan et al, 2003). As acetycholinesterase inhibitors are nonspecific in their effects, targeting both nicotinic and muscarinic receptors, it is difficult to assess the potential of each subtype as a target for remediation strategies and its role in side effects. The genetic study by Liao et al (2003) suggests that involvement of $\mathrm{M} 1$ receptors might be critical in the genesis of cognitive deficits in schizophrenia, and therefore M1 receptor agonism might be a good remediation strategy for the treatment of the cognitive dysfunction in schizophrenia.

In vivo neuroimaging studies using subtype selective radioligands with appropriate potency, efficacy, and pharmacokinetic properties are necessary for the better understanding of the role of each muscarinic receptor in cognitive processes. Future development of a muscarinic agonist that can produce improvements in cognitive performance without producing side effects is warranted and may prove useful in treating the cognitive deficits associated with schizophrenia. However, since abnormalities in noncholinergic systems that are modulated by acetylcholine have been reported in the ACC in schizophrenia (Zavitsanou and Huang, 2002; Zavitsanou et al 2002), pharmacologic treatment of cognitive symptoms through manipulations of these neurotransmitter systems merits investigation. 


\section{REFERENCES}

Anagnostaras SG, Murphy GG, Hamilton SE, Mitchell SL, Rahnama NP, Nathanson NM et al (2003). Selective cognitive dysfunction in acetylcholine M1 muscarinic receptor mutant mice. Nat Neurosci 6: 51-58.

Buchanan RW, Summerfelt A, Tek C, Gold J (2003). An openlabeled trial of adjunctive donepezil for cognitive impairments in patients with schizophrenia. Schizophr Res 59: 29-33.

Bush G, Luu P, Posner MI (2000). Cognitive and emotional influences in anterior cingulate cortex. Trends Cogn Sci 4: 215-222.

Crook JM, Tomaskovic-Crook E, Copolov DL, Dean B (2001). Decreased muscarinic receptor binding in prefrontal cortex from subjects with schizophrenia: a study of Brodmann's areas 8,9 , 10 , and 46, and the effects of neuroleptic drug treatment. Am J Psychiatry 158: 918-925.

Dean B, McLeod M, Keriakous D, McKenzie J, Scarr E (2002). Decreased muscarinicl receptors in the dorsolateral prefrontal cortex of subjects with schizophrenia. Mol Psychiatry 7: 1083-1091.

Felder CC, Porter AC, Skillman TL, Zhang L, Bymaster FP, Nathanson NM et al (2001). Elucidating the role of muscarinic receptors in psychosis. Life Sci 68: 2605-2613.

Friedman JI, Temporini H, Davis KL (1999). Pharmacologic strategies for augmenting cognitive performance in schizophrenia. Biol Psychiatry 45: 1-16.
Goldman-Rakic PS (1987). Circuitry of the primate prefrontal cortex and the regulation of behavior by representational memory In: Plum F (ed). Handbook of Physiology: The Nervous System, Higher function of the Brain. American Physiological Society: Bethesda, MD. Vol 5 pp 373-417.

Liao DL, Hong CJ, Chen HM, Chen YE, Lee SM, Chang CY et al (2003). Association of muscarinic $\mathrm{ml}$ receptor genetic polymorphisms with psychiatric symptoms and cognitive function in schizophrenia patients. Neuropsychobiology 48: 72-76.

Raedler TJ, Knable MB, Jones DW, urbina RA, Gorey JG, Lee KS et al (2003). In vivo determination of muscarinic acetylcholine receptor availability in schizophrenia. Am J Psychiatry 160: 118-127.

Zavitsanou K, Huang XF (2002). Decreased $\left[{ }^{3} \mathrm{H}\right]$ spiperone binding in the anterior cingulate cortex of schizophrenia patients: an autoradiographic study. Neuroscience 109: 709-716.

Zavitsanou K, Katsifis A, Mattner F, Huang XF (2004). Investigation of M1/M4 muscarinic receptors in the anterior cingulate cortex in schizophrenia, bipolar disorder and major depression disorder. Neuropsychopharmacology 29: 619-625.

Zavitsanou K, Ward P, Huang XF (2002). Selective alterations in ionotropic glutamate receptors in the anterior cingulate cortex in schizophrenia. Neuropsychopharmacology 27: 826-833. 